\title{
Zika virus and birth defects: an obstetric issue
}

\section{Tochukwu C. Okeke ${ }^{1 *}$, Cyril C. Ezenyeaku², Lawrence C. Ikeako ${ }^{2}$, Kenechukwu O. Okeke ${ }^{3}$, Fidelis A. Onyekwulu ${ }^{4}$, Christain I. Okafor ${ }^{5}$, Charles O. Adiri ${ }^{1}$}

\author{
${ }^{1}$ Department of Obstetrics and Gynaecology, UNTH, Enugu, Nigeria \\ ${ }^{2}$ Department of Obstetrics and Gynaecology, Chukwuemeka Odumegwu-Ojukwu University Teaching Hospital, \\ Amaku, Awka, Nigeria \\ ${ }^{3}$ College of Medicine, UNEC, Enugu Campus, Enugu, Nigeria \\ ${ }^{4}$ Department of Anaesthesia, UNTH, Enugu, Nigeria \\ ${ }^{5}$ Department of Medicine, UNTH, Enugu, Nigeria
}

Received: 07 June 2016

Accessed: 01 July 2016

*Correspondence:

Dr. T.C. Okeke,

E-mail: tcokeke2014@yahoo.com

Copyright: (c) the author(s), publisher and licensee Medip Academy. This is an open-access article distributed under the terms of the Creative Commons Attribution Non-Commercial License, which permits unrestricted non-commercial use, distribution, and reproduction in any medium, provided the original work is properly cited.

\begin{abstract}
Zika virus is an emerging mosquito-borne virus that is relatively unknown, unstudied and under-diagnosed, but has potentials to spread to new geographical areas that favour survival of Aedes mosquitoes. It is associated with an alarming rise in babies with microcephaly that require much care and support with a lot of financial assistance. This is a review article on Zika virus and birth defects; a worrisome issue in today's obstetric and medical practices. Since Zika's discovery in Uganda, the virus was known to occur within a narrow equatorial belt from Africa to Asia with no or mild symptoms. It has emerged as a global public health threat over the last decade with accelerated geographic spread of the virus in the last nine years. The risk of Zika virus to the fetus is poorly understood, difficult to quantify and problematic. The causal link between Zika virus and microcephaly was initially speculative, strongly suspected and scientifically unproven. However, on 13th April, 2016, it was concluded that Zika virus is the cause of microcephaly and other severe fetal brain defects. The Center for Disease Control and Prevention (CDC) authors reviewed and weighed evidences using established scientific criteria to conclude after a careful review of the report published in the New England Journal of Medicine. There is no prophylaxis, treatment or vaccine to protect against Zika virus infection. However, preventive personal measures are highly recommended to avoid mosquito bites.
\end{abstract}

Keywords: Zika virus, Birth defect, Pregnancy, Obstetric issue, Flaviviruses

\section{INTRODUCTION}

Zika virus is an emerging viral infection which is borne by mosquitoes. This viral infection is a relatively unknown, unstudied, and under-diagnosed disease that has the potentials to spread to new geographical areas that favour survival of Aedes Mosquitoes. ${ }^{1}$ It is a flavivirus transmitted by active day-time Aedes mosquitoes that feeds almost exclusively on humans. ${ }^{2}$ The name Zika is derived from the Zika forest of Uganda where it was first isolated from a monkey in $1947 .^{3-6}$
Zika virus is related to other flaviviruses like dengue fever, West Nile, and Japanese encephalitis. ${ }^{6-8}$

Zika virus often caused no or mild symptoms in the past. Since the 1950s, it has been known to occur within a narrow equatorial belt from Africa to Asia. The first major outbreak outside Africa occurred in 2007 in the Yap Islands of Micronesia, with another large outbreak in 2013 in French Polynesia. ${ }^{9,10}$ In 2015, the virus spread to Mexico, Central Africa, the Caribbean, and South America, where the Zika outbreak has reached pandemic levels. $^{11}$ 
Apart from the concerns over its rapid geographic spread, Zika has received much attention from public health officials because of its highly suspected association with feto-maternal transmission and newborn microcephaly with other neurological abnormalities. ${ }^{12-15}$ In February, 2016, there was evidence that Zika fever in pregnant women can result in abnormal brain development in their fetuses through mother-to-child transmission either by miscarriage or microcephaly. ${ }^{13-15}$ The causal links was speculative but it is now proven that Zika virus causes microcephaly. ${ }^{16,17}$

There was an alarming rise of microcephaly in babies born in Brazil. Microcephaly babies are personal tragedies for the families affected because they require much care and support for decades and will need a lot of financial assistance. The rapid rise in the incidence of microcephaly during this period of recent geographic expansion of Zika has caused the United States Centre for Disease Control and Prevention (CDC) to advise pregnant women to consider postponing travel to any area where Zika transmission is on-going. ${ }^{12,13}$

Recently, World Health Organization (WHO) issued a statement that Zika is "spreading explosively" and that the associated level of concern is 'extremely high'. ${ }^{18}$ This was followed by the declaration (Feb 2, 2016) of Public Health Emergency of International Concern (PHEIC) around the current outbreak. ${ }^{19}$ The following countries, Colombia, the Dominican Republic, Ecuador, ElSalvador and Jamaica advised women to postpone getting pregnant until more is known about the risk. ${ }^{20}$

Zika has become more of a global threat over the past decade because of its rapid geographic spread, first to the Asia Pacific region, followed by its rapid entry into the Western hemisphere. ${ }^{5-9,21-23}$ Thus, the need for this review of the characteristics of Zika virus, obstetric issue and controversies associated with Zika virus infection.

This is a 6-month descriptive review of Zika virus and birth defects. Relevant literature search on this topic was from December $1^{\text {st }} 2015$ to May $31^{\text {st }}$ 2016. A search of literature on Zika virus published in English was conducted. Relevant materials were selected. We searched several databases on Zika virus from inception to May $31^{\text {st }} 2016$ with keywords “Zika virus, Zika and birth defects, Zika and pregnancy, and flaviridae viruses".

We also searched references in retrieved articles, book chapters, review articles, conference papers, technical reports, abstracts and internet articles using Medline, Google scholar, PubMed, Embase and Cochrane primary databases. A manual search from the references of narrative reviews was also done. These materials were critically reviewed and the inclusion of individual articles was based on scientific merit and clinical relevance.

\section{Historical perspectives}

Zika virus was first discovered from a rhesus Macaque monkey in the Zika forest of Uganda in 1947 by the scientists of the yellow fever research institute. ${ }^{4,24,25}$ In 1948 , it was isolated from the mosquito A. africanus in the same forest and in 1952 a Nigerian human was found to habour the virus. ${ }^{4,5}$ This came as part of investigative processes of a 1952 outbreak of jaundice suspected to be yellow fever. She recovered within 3 days. ${ }^{4}$ Zika virus was first described in a scientific paper in $1952 .{ }^{4}$

A research study conducted in India in 1952 showed that a "significant number" of Indians tested for Zika had exhibited an immune response to the virus, indicating that it had long been widespread within human populations. ${ }^{27}$ An increasing amount of evidence pointed to human illness associated with Zika virus transmission between early 1950s-1980s. ${ }^{28,29}$ Human Zika infections were known to present with nonspecific signs and symptoms, which often were similar to that of dengue fever. ${ }^{28,29}$ Prior to 1952, Africa and Asian serological surveys was a silent Zika virus circulation with detection of specific antibodies in various animal species (orangutans, zebra, elephants and water buffaloes) and rodents. The knowledge of geographical distribution of Zika virus is based on results of sero-surveys and viral isolation in mosquitoes and humans, with reports of travel associated cases.

Evidence of human infection with Zika virus was documented from other African countries (from 1951 1981) such as the Central African Republic, Egypt, Gabon, Sierra Leone, Tanzania, Uganda and some parts of Asia like India, Indonesia, Malaysia, the Philippines, Thailand and Vietnam. ${ }^{30}$ Before 2007, the areas with reported outbreak of Zika virus infections were Tropical Africa and Southeast Asia. There were only 14 confirmed human cases of Zika virus infection from Africa and Southeast Asia from its discovery up to $2007 .^{31}$

The first outbreak outside Africa and Asia was in April July 2007 in the Yap Island, Federated States of Micronesia. ${ }^{32}$ The geographic distribution of reported cases and outbreaks has expanded overtime with human Zika infections reported in Nigeria, Island of Yap in Micronesia, Cambodia, Thailand, French Polynesia and Brazil. ${ }^{5-10,21-23,32-34}$ The Brazilian outbreak first identified in May 2015, is the largest so far reported. The cases are centered in northeastern states of Paraiba, Permambuco and Bahia. Zika quickly spread to these states because the population had never been exposed to the virus: thus, resulting in high susceptibility. It is well reported and evident that Zika virus has spread outside Africa and Asia (the two primary regions where the virus actually started). ${ }^{29}$

Since 2015 there has been a rapid geographic outbreak of Zika virus from Brazil and other South American and Mesoamerican countries to the United States. ${ }^{7,35-37} \mathrm{Zika}$ 
virus in Brazil raises concerns about the potential dangers of infestation by Aedes stegomyia mosquitoes. ${ }^{7}$ However, the risk of Zika virus adaptation to life cycles based in densely populated urban environments coupled with human transmission/amplification via Aedes aegypti and other stegomyia subgenus mosquito vector certainly poses a significant (local and global) health security threat. $^{29}$

In January 2016, the CDC issued a level 2 travel alert for people traveling to regions and certain countries where Zika virus transmission is ongoing, and suggested that women who desire pregnancy should consult their physicians before traveling. ${ }^{38-40}$

Brazilian health authorities between October 2015 and January 2016 reported more than 350 cases of microcephaly, some with a severe type, while some are dead. ${ }^{41}$ The worst affected region of Brazil is its poorest region of the three northeastern states: Paraiba, Permambuco, and Bahia where about $1 \%$ of newborns are suspected having microcephaly. ${ }^{42}$ United States (US) and World Health officials in March 2016, said that mounting scientific evidence points to the mosquito born virus as the likely cause of the alarming rise in microcephaly in the Zika hit areas of Brazil. ${ }^{43}$

Dr. Tom Frieden, Director of the US CDC, told reporters in a conference on Wednesday, $13^{\text {th }}$ April, 2016, that there isn't any doubt that Zika causes microcephaly. He said that after a careful review of the report published in the New England Journal of Medicine, the CDC authors rigorously weighed and assessed evidences using established scientific criteria to conclude that Zika virus is the cause of microcephaly and other severe fetal brain defects. ${ }^{17,44}$ This study marks a turning point in the Zika virus outbreak. It is now clear that Zika virus causes microcephaly.

\section{The pathogenic virus called Zika}

Zika virus disease is caused by a virus from the flavivirus genus, flaviviridae family from the spondweni group. ${ }^{45}$ It is related to the dengue, yellow fever, Japanese encephalitis, and West Nile viruses. Zika virus is enveloped icosahedral and has a non-segmented, singlestranded, positive-sense RNA genome. ${ }^{30,46}$ There are two Zika virus lineages: the African lineage and the Asian lineage which has recently emerged in the pacific and the Americas. $^{24,30}$

Zika belongs to flaviviridae which posses an infectious viral particle (virion) that has an outer lipid membrane in which are embedded the viral envelope protein (E) and membrane protein $(\mathrm{M}) .^{45,47,48}$ The virion contains an icosahedral nucleocapsid of around $50-60 \mathrm{~nm}^{45,47,48}$ This is composed of the capsid protein $(\mathrm{C})$, and a genome consisting of a single strand of positive-sense RNA of approximately 11,000 - 12,000 bases that serves both as a genome and a messenger RNA. ${ }^{49}$ The virion attaches via the $\mathrm{E}$ protein to a receptor on the cell targeted for infection. The virion is brought into the cell by a process called clathrin-mediated endocytosis, which causes the envelope to be removed, the nucleocapsid to be disrupted, and the genome released into the cytoplasm. ${ }^{50,51}$ The genome is translated by the host cells translational apparatus into a single polyprotein that is proteolytically cleaved into the individual viral proteins. ${ }^{52,53}$ Some of these proteins form the RNA replication machinery, which causes the production of more genomes by using the negative-sense RNA copy of the viral genome as a template. The genomes are then assembled into nucleocapsids by interaction with capsid protein (C), and the nucleocapsids become enveloped during the budding process that releases them from the cell as infectious virions. $^{45,47,49}$

\section{Clinical presentation}

In the past, Zika fever was asymptomatic in $80 \%$ of cases with relatively mild condition of limited scope. It was neither associated with fatalities nor was it linked with any serious disease. ${ }^{24}$ However, in recent times, most people infected with Zika virus present with mild headache, fever, maculopapular rash, malaise, joint pains and conjunctivitis.

The incubation period for Zika virus disease ranges between 3-12 days after the bite of an infected A. aegypti mosquito. Zika virus infection resolves within five days. ${ }^{34}$ The clinical presentation coupled with appropriate travel history, should guide the clinician to suspect Zika virus infection. Once an individual is infected, he or she is likely to be protected from future infections.

\section{Diagnosis}

Diagnosis of Zika virus disease is primarily based on detection of viral RNA from clinical specimens in acutely ill patients by performing a reversed transcriptasepolymerase chain reaction (RT-PCR) on the serum. ${ }^{54}$ The viraemic period is short allowing for direct virus detection during the first 3-5 days after the onset of symptoms. Zika virus RNA has also been detected in urine up to 10-days after onset of the disease. Diagnostic testing is accurate but serological investigations are limited. ${ }^{6}$

Serological investigations can be conducted from the $5^{\text {th }}$ day post onset of disease by detection of Zika specific $\operatorname{IgM}$ and neutralizing antibodies within 7-days of illness, but they are not specific and there may be cross-reaction with dengue virus and yellow fever virus. ${ }^{54}$ Serological results should be interpreted according to the previous exposure to other flaviviral infections. ${ }^{55}$

\section{Transmission}

Zika virus is transmitted primarily by day time active Aedes aegypti mosquitoes as its vector. This is seen in a 
mosquito-human-mosquito cycle, like the yellow fever virus and the dengue fever virus (both flaviviuses), and the chikungunya virus (a togavirus). ${ }^{56}$ However, it is to be noted that Zika virus has been isolated from a number of abortal mosquito species in the Aedes genus such as $A$. africanus, A. apicoargenteus, A. furcifer, A. hensilli, A. luteocephalus and $A$. vittatus with a short extrinsic incubation period in mosquitoes of about 10 days. ${ }^{24}$

Earlier when Zika virus was discovered, the vertebrate hosts of the virus were primarily monkeys in enzootic mosquito-monkey-mosquito cycle, with rare transmission to humans before the recent pandemic began in 2007. Zika virus "rarely caused recognized "outbreak" infections in humans, even in highly enzootic areas. ${ }^{56}$ Sporadically, other arboviruses have become established as a human disease like yellow fever virus, dengue fever virus and chikungunya virus. ${ }^{56}$

The true understanding of the vector is still poor. The Zika virus has been detected in some other species of Aedes, along with Anopheles constani, Mansonia uniformis, and Cudex perfuscus. ${ }^{57}$ This however, does not make them to be recognized as vectors. Recent pandemic outbreak of Zika virus in 2015 has been documented: the spread to Latin America and the Caribean. ${ }^{58}$

The countries and territories that have been identified by the Pan American Health Organization as having experienced "local Zika virus transmission" are Barbados, Bolivia, Brazil, Colombia, the Dominican Republic, Ecuador, El-Salvador, French Guiana, Guadeloupe, Guatemala, Guyana, Haiti, Honduras, Martinique, Mexico, Bahamas, Paraguay, Puerto Rico, Saint Martin, Suriname and Venezuela. ${ }^{59}$

Several modes of transmission have been identified. These include transmission: from mother to child, through sexual contact, and through blood transfusion.

\section{From mother to child}

An infected mother with Zika virus can transmit the virus to her newborn during pregnancy and parturition. Zika virus RNA was detected in the amniotic fluid of two pregnant women whose fetuses had microcephaly, showing that the virus had crossed the placenta and could have caused a mother to child infection. ${ }^{60}$ This link of intra-uterine infection was thought possible before February 2016 but was unproven. ${ }^{13}$ It is now certain that Zika virus can cause a mother to child infection. ${ }^{60}$ In addition, brain tissue from two newborns with microcephaly who died within 20hours of birth and placenta and other tissues of two miscarriages (11 and 13 weeks from Rio Grande do Norte in Brazil tested positive for Zika virus) by RT-PCR at the CDC. ${ }^{14}$

In February, 2016, WHO said that a causal link between the Zika virus and microcephaly was strongly suspected but still not scientifically proven. Investigations and research was still needed to understand this potential link between Zika virus and microcephaly. ${ }^{61}$

The United States CDC updated its health care provider guidelines for pregnant women and women of reproductive age in february 2016. The new recommendations include offering serologic testing to pregnant women without Zika fever symptoms who have returned from areas with ongoing Zika virus transmission in the last 2-12 weeks, and for pregnant women without Zika symptoms living in such areas. They recommended testing at the beginning of prenatal care and follow-up testing in the fifth month of pregnancy. ${ }^{62}$

\section{Through sexual contact}

Zika virus can be transmitted by a man to his sexual partners. Zika virus capable of reproducing itself was found in the semen of a man at least two weeks after he fell ill with Zika fever in 2014..$^{29,63}$ In February 2016, there were up to 3 documented cases that Zika virus could possibly be sexually transmitted. ${ }^{63}$ It is also known that Zika virus is present in semen longer than in blood but it is unknown whether women can transmit Zika virus to their sexual partners. ${ }^{63}$

\section{Through blood transfusion}

There have been multiple reports of blood transfusion transmission cases in Brazil and French Polynesia. These reports are currently being investigated. ${ }^{64}$

\section{Zika virus and pregnancy}

A pregnant woman can be infected with Zika virus through the bite of infected A. aegypti mosquito, sexually transmitted from her partner or through infected blood transfusion.

Zika viruses replicate in, and are transmitted by mosquitoes to humans. ${ }^{65}$ When an infected blood feeding Aedes aegypti mosquito with Zika virus injects the virions into the skin of a pregnant woman, this is followed by infection of cells in the dermis and epidermis. ${ }^{50}$ From the dermis and epidermis, the virus spreads to the lymph nodes where an immune reaction is initiated and the virus is replicated causing a viraemia. It is not yet well understood how the Zika virus crosses the placenta to infect the developing fetus, however, this unique ability of Zika virus to cross the placenta and affect the developing fetus is still under confirmation. ${ }^{66}$ The highly suspected association and link between Zika virus and microcephaly has been the global threat of Zika virus world-wide. ${ }^{19}$

Zika virus can be transmitted from a pregnant woman to her fetus during pregnancy or at delivery and has been linked to a serious birth defect called microcephaly in babies of mother who had Zika virus while pregnant. ${ }^{19}$ 
There are other birth defects detected among fetuses and infants infected with Zika virus before birth such as absent or poorly developed brain structures, defects of the eye, hearing defects and impaired growth. ${ }^{67}$ In view of these, CDC recommends special precautions for pregnant women. Pregnant women should not travel to areas with Zika virus. If they must travel to any of these areas, they must strictly follow steps to prevent mosquito bites during such trips.

Up till date, no vaccine exists to prevent Zika virus disease. There is no proven specific medical treatment for Zika virus. ${ }^{68}$ Treatment is aimed at easing symptoms such as rest, plenty of oral fluids ingestion and medications such as acetaminophen (paracetamol) for pain. Asprin and other NSAIDS should be avoided until dengue fever has been ruled out to avoid haemorrhagic complications. $^{12,68-70}$

Pregnant women with evidence of Zika virus in their blood or amniotic fluid, should have serial ultrasound examinations to monitor fetal anatomy and growth developments every 3-4 weeks. ${ }^{71}$ Managing clinicians should urgently consider referral to a feto-maternal medicine specialist or infectious diseases specialist with expertise in pregnancy management. ${ }^{71}$

The rate of microcephaly has increased in recent times in Zika virus affected areas but the exact cause of this anomaly is still not clearly understood. Early documented investigations/researches performed to describe the detailed link between the Zika virus and microcephaly produced mixed results. $^{72}$ Though in April, 2016, WHO Accessed a causal link between microcephaly and the virus. $^{73}$

Pregnant women are at the greatest risk of having babies with birth defects if they are infected in the $1^{\text {st }}$ trimester. Women infected with Zika during the $1^{\text {st }}$ trimester of their pregnancies face 1 in 100 chance of delivering a baby with microcephaly. ${ }^{74}$ Zika virus has detrimental effects on the fetus and the greatest risks occur during the first trimester of pregnancy. When the organ-system is forming, the Zika virus can have detrimental effects. In adults, Zika is asymptomatic or may present a mild disease in most people.

A woman who is infected with Zika during pregnancy has an increased risk of having a baby with these health problems. However, not all women who have Zika virus infection during pregnancy will have babies with problems. Some infected women may deliver babies that appear to be healthy while others may have babies with severe potential consequences such as microcephaly, Guillain-Barre Syndrome (GBS) and other inborn defects.

Zika virus is the first mosquito-borne virus to threaten fetus. $^{75}$ Researchers have also documented a causal association between Zika and GBS. WHO reported that
13 countries or territories battling Zika outbreaks have noted an increased incidence of GBS. ${ }^{76}$ There are other reports of other neurological complications related to the virus: Zika and meningo-encephalitis, acute disseminated encephalomyelitis, as well as acute myelitis: dangerous inflammation of the brain and spinal cord brought on by an infection.

Pregnant women should avoid travel to areas where Zika is actively spreading ${ }^{77}$. When a pregnant woman travels to or lives in an area with active Zika virus transmission, she should talk with her healthcare provider and strictly follow steps to prevent mosquito bites and to prevent sexual transmission of Zika virus. Women and their partners in areas with active Zika transmission should engage in family planning and counseling with their healthcare providers to enable them understand the risks and ways to mitigate them. ${ }^{77}$

\section{Confirmation that Zika causes microcephaly}

In February 2016, WHO declared Zika a global health emergency based on its suspected link to thousands of cases of microcephaly, in Brazil. This declaration kicked off a lot of studies to prove a link. After thorough review of the report published in the New England Journal of medicine, the CDC authors assessed evidences using established scientific criteria to conclude that Zika virus is the cause of microcephaly and other severe fetal brain defects. $^{17,78}$

CDC reported that no single evidence provides conclusive proof that Zika virus infection is the cause of microcephaly and other fetal brain defects. However, increasing evidence from a number of recently published studies and a careful evaluation using established scientific criteria supports the authors' conclusions. It is now clear that Zika virus causes microcephaly. The study published in the New England Journal of Medicine marks a turning point in the Zika virus outbreak. ${ }^{17,79}$

Dr. Tom Frieden, Director of the US CDC, told reporters in a conference on Wednesday $13^{\text {th }}$ April, 2016 that there is not any doubt that Zika causes microcephaly. ${ }^{80}$ Certainty over whether Zika causes microcephaly should end the debate in the public health community about the potential impact of the virus and focus attention on how to prevent infections. ${ }^{81}$

\section{Controversies/problems with Zika virus infection}

1. Zika virus has been associated with a high rate of misdiagnosis. It is difficult for clinicians to determine who has been infected and who has not because diagnostic tests for Zika virus have limitations. Test which detects viral RNA in a patient's blood can only work in the first week of the onset of symptoms. Serological test for the detection of IgM antibodies can be done after $1^{\text {st }}$ week of symptoms and it is not specific. Serological 
tests to detect Zika antibodies cross react with antibodies to dengue.

2. It is not all babies born to mothers who had Zika virus while pregnant will have birth defects, but the amount of risk is still controversial. The stage of pregnancy at the time of infection has not been fully linked with the risk or outcome of Zika infection. The virus is expected to be toxic in the first two months of pregnancy when the fetal brain is still developing its major structures. However, Zika is seen in stillborn babies with microcephaly. The question is why is Zika virus present at seven months when the miscarriage occurred, if the insult happened early in intrauterine period? Could it be a combination of events or mixed?

3. It is true that Zika virus like other related viruses such as West Nile virus crosses from mother to baby through the placenta. These other viruses don't often cause infant brain damage which is seen in Zika virus. A lot of basic work and research need to be done to back up with the clinical presentation of microcephaly.

4. What makes women and babies more vulnerable? Why is fetal brain more vulnerable to Zika virus insult?

5. The outcome of microcephaly on children, challenges and problems of supporting children with microcephaly.

Epidemiological studies are complex and Zika virus is known to cause a relatively mild illness in adults and there is no widely deployed test for Zika virus. Some infected women could have been missed in studies done in Brazil. Clinicians refused to accept epidemiological data alone to convince them of a link between Zika virus and microcephaly. ${ }^{82}$ They want evidence to support how and why the virus causes microcephaly. This is a problem and a huge challenge.

\section{Funding: No funding sources}

Conflict of interest: None declared

Ethical approval: Not required

\section{REFERENCES}

1. Clark C. Zika virus 'a game-changer' for mosquito borne diseases. A Science commons Jan. 24, 2016. Available at:http://esciencecommons.blogspot.com.

2. Pierson TC, Diamond MS. Flaviviruses. In: Knipe DM, Howley PM, eds. Fields Virology. $6^{\text {th }}$ ed. Chapter 26. Philadelphia, Pennsylvania, USA: Wolters Kluwer/Lippincott Williams and Wilkins Health; 2013;00:747-94.

3. Dick GW. Zika virus. II. Pathogenicity and Physical Properties. Trans R Soc Trop Med Hyg. 1952;46:521-34.
4. Dick GW, Kitchen SF, Haddow AJ. Zika virus. I. Isolations and serological specificity. Trans R Soc Trop Med Hyg. 1952;46:509-20.

5. Macnamara FN. Zika virus: a report on three cases of human infection during an epidemic of jaundice in Nigeria. Trans R. Soc Trop Med Hyg. 1954;48:13945.

6. Sikka V, Chattu VK, Popli RK, Galwankar SC, Kelkar D, Sawicki SG, et al. The emergence of Zika virus as a global health security threat: a review and a consensus statement of the INDUSEM Joint Working Group (JWG). J Global Infect Dis. 2016;8:3-15.

7. Marcondes CB, Ximenes MF. Zika Virus in Brazil and the danger of infestation by Aedes (stegomyia) mosquitoes. Rev Soc Bras Med Trop. 2015;pii: S0037-86822015005003102.

8. Buathong R, Hermann L, Thaisomboonsuk B, Rutvisuttinunt W, Klungthong C, Chinnawirotpisan $\mathrm{P}$, et al. Detection of Zika virus infection in Thailand, 2012-2014. Am J Trop Med Hyg. 2015;93:380-383.

9. Lanciotti RS, Kosoy OL, Laven JJ, Valez JO, Lambert AJ, Johnson AJ, et al. Genetic and Serologic properties of Zika virus associated with an epidemic, Yap State, Micronesia, 2007. Emerg Infect Dis. 2008;14:1232-9.

10. Oehler E, Watrin L, Larre P, Leparc Goffart I, Lastere S, Valour F, et al. Zika virus infection complicated by Guillain-Barre syndrome-case report, French Polynesia, December 2013. Euro Surveill. 2014:19pii:20720.

11. Chastain, Mary, National Institutes of health. Zika virus is a pandemic. Breitbart 30th January 2016. Retrieved $15^{\text {th }}$ February 2016.

12. European_Centre_for_Deasese_prevention_and_cont rol. Rapid Risk Assessment: Zika virus epidemic in the Americas: Potential association with microcephaly and Guillain-Barre syndrome; 2015. Accessed on February 16, 2016.

13. Oliveira Melo AS, Malinger G, Ximenes R, Szeinfeld PO, Alves Sampaio S, Bispo de Fillippis AM. Zika virus intrauterine infection causes fetal brain abnormality and microcephaly: Tip of the iceberg? Ultrasound Obstet Gynecol. 2016;47:6-7.

14. Martines RB, Bhatnagar J, Keating MK, SilvaFlannery L, Muehlenbachs A, Gary J, et al. Notes from the field: Evidence of Zika virus Infection in Brain and placental tissues from two congenitally infected Newborns and two fetal losses. Brazil, MMWR. 2015;65(6):1-2.

15. Mlakar J, Korva M, Tul N, Popovic M, PoljsakPrijatelj M, Mraz J, et al. Zika virus Associated with Microcephaly. New England Journal of Medicine. 2016;374:951-8.

16. Question and Answers: Zika virus infection (Zika) and pregnancy. CDC. CDC. Retrieved 16rd March 2016.

17. Rasmussen SA, Jamieson DJ, Honein MA, Petersen LR. Zika virus and birth defects-Reviewing the 
evidence for causality. N Engl J Med. 2016;374:1981-7.

18. Cha AE. Sun LH. WHO: Zika virus 'spreading explosively', level of alarm 'extremely high'. Accessed https://www.washingtonpost.com/news/to-yourhealth/wp/2016/01/28/Zika-virus-who-announcesformation-of-emergency-committee-level-of-alarmextremely-high/2016.

19. Grenoble R, Almendrala A, Schumaker E. WHO declares public health emergency around Zika virus; 2016. Accessed at: http://www.huffingtonpost.com/entry/world-healthorg-Zika-virus-emergency-

us56af78/ae4b077d4fe8ec2ac. Accessed on March 16 th 2016.

20. Pregnant Irish Women warned over Zika virus in central and South America. RTE. 22 ${ }^{\text {nd }}$ January 2016. Accessed 24 February 2016.

21. Fagbami AH. Zika virus infections in Nigeria: Virological and Seroepidemiological Investigations in Oyo State. J Hyg (Lond). 1979;83:213-9.

22. Heang V, Yasuda CY, Sovann L, Haddow AD, Travassos da Rosa AP, Tesh RB, et al. Zika virus infection. Cambodia 2010. Emerg Infect Dis. 2012;18:349-51.

23. McCarthy M. Zika virus outbreak prompts US to issue travel alert to pregnant women. BMJ. 2016;352:306.

24. Hayes EB. Zika virus outside Africa. Emerg Infect Dis. 2009; $15: 1347-50$.

25. Zika's long, strange trip into the limelight". Science. American Association for the Advancement of Science. Accessed on $16^{\text {th }}$ February 2016.

26. Weinbren MP, Williams MC. Zika virus: further isolations in the Zika area, and some studies on the strains isolated. Trans R Soc Trop Med Hyg. 1958;52:263-8.

27. Rowlatt J. Why Asia should worry about Zika tooBBC News. BBC News. 2 $2^{\text {nd }}$ February 2016. Accessed 2 February, 2016.

28. Haddow AD, Schuh AJ, Yasuda CY, Kasper MR, Heang V, Huy R, et al. Genetic characterization of Zika virus strains: Geographic expansion of the Asian lineage". PloS Neglected Tropical Diseases 2012;6(2):e1477.

29. Musso D, Cao-Lormeau VM, Gubler DJ. Zika virus: following the path of dengue and chikungunya? Lancet. 2015;386:243-4.

30. Faye O, Freire CC, Lamarino A, Faye O, de Oliveira JV, Diallo M, et al. Molecular evolution of Zika virus during its emergence in the $20^{\text {th }}$ century. PLoS Neg1 Trop Dis. 2014;8:e2636.

31. PAHO/WHO PAHO Statement on Zika virus. Transmission and Prevention: 2016. http://www.paho.org/hg/index.php?option=com_cont ent\&view $=$ article $\& i d=11605 \& I \quad$ temid=o\&lang=en. Accessed on February 16, 2016.
32. Musso D, Nilles EJ, Cao-Lormeau VM. Rapid spread of emerging Zika virus in the pacific area. Clin Microbiol Infect. 2014;20(10):0595-6.

33. Altman LK. Little-known virus challenges a farflung Health System. New York Times. $3^{\text {rd }}$ July, 2007.

34. Duffy MR, Chen TH, Hancock WT, Powers AM, Kool JL, Lanciotti RS, et al. Zika virus outbreak on Yap Island, Federal States of Micronesia. New England Journal of Medicine. 2009;360(24):253643.

35. Campos GS, Bandeira AC, Sardi SI. Zika virus outbreak, Bahia Brazil. Emerg Infect Dis. 2015;21:1885-6.

36. McKay B, Johnson R. Texas Woman diagnosed with mosquito-borne Zika virus, 2016. http://www.paho.org/hq/index/php?option=com_doc man\&task=doc_download $\&$ Itemid= $\&$ gid $=32405 \& l a$ ng=en. Accessed on February $18^{\text {th }}, 2016$.

37. McNeil DG Jr. Hawaii baby brain damage is first US case tied to Zika virus; 2016. http://www.paho.org/hq/index/php?option=com_doc man \&task=doc_download $\&$ Itemid $=\&$ gid $=32405 \&$ la ng=en. Accessed on February 18, 2016.

38. Zika Travel Health Notices. Accessed on www.cdc.gov. CDC Retrieved February 20, 2016.

39. Lowes R. CDC Issues Zika Travel Alert. CDC. $15^{\text {th }}$ January 2016. Accessed on February 20, 2016.

40. Zika virus: Advice for those planning to travel to outbreak areas. ITV News. 22 $2^{\text {nd }}$ January 2016. Accessed $20^{\text {th }}$ February 2016.

41. Microcephaly in Brazil potentially linked to the Zika virus epidemic, ECDC assesses risk". European centre for disease prevention and control. Accessed on $20^{\text {th }}$ February, 2016.

42. Brazil Zika Outbreak: More babies born with birth defects. BBC 21nd January 2016.

43. Erika Check Hayden. Proving Zika Link to Birth defect poses huge challenge. Schneyder Mendoza/AFP/Getty. 17 February 2016. Accessed on 20 February 2016.

44. Associated Press. Zika virus confirmed as cause of microcephaly birth defect, CDC says. $13^{\text {th }}$ April 2016, 22.40BST.

45. Lindenbach BD, Murray CL, Thiel HJ, Rice CM. Flaviridae. In: Knipe DM, Howley PM, eds. Fields virology. $6^{\text {th }}$ ed. Chapter 25. Philadelphia. Pennsylvania, USA: Wolters Kluwer/Lippincott Williams and Wilkins Health; 2013.

46. Knipe DM, Howley PM. Fields virology. $5^{\text {th }}$ ed. Lippincott Williams and Wilkins; 2007:1156-99.

47. Kuhn RJ, Zhang W, Rossmann MG, Pletnev SV, Corver J, Lenches E, et al. Structure of Dengue virus: Implications for flavivirus organization, maturation and fusion. Cell. 2002;108:717-25.

48. Hamel R, Dejarac O, Wichit S, Ekchariyawat P, Neyret A, Luplertlop N, et al. Biology of Zika Virus infection in human skin cells. J Virol. 2015;89:888096. 
49. Ramamurthy M, Srikanth P, Seshan V, Sarangan G, Sankar S, Nandagopal B, et al. Aboviruses of importance in India: Part I, Biological, Transmission characteristic, certain unique issues and clinical feature. Sri Ramachanda J med. 2013;68:22-30.

50. Carnec X, Meertens L, Dejarnac O, perera-Lecoin M, Hafirassou ML, Kitaura J, et al. The phosphatidyl serine and phosphatidylethanolamine receptor $\mathrm{CD}$ 300a binds Dengue virus and enhances infection J Virol. 2015;90:92-102.

51. Chu JJ, Ng ML. Infections entery of west Nile virus occurs through a clathrin-mediated endocytic pathway. J Virol. 2004;78:10543-55.

52. Falgout B, Chanock R, Lai CJ. Proper Processing of Dengue virus non-structural glycoprotein NS1 requires the $\mathrm{N}$-terminal hydrophobic signal sequence and the downstream nonstructural protein NS2a. J Virol. 1989;63:1852-60.

53. Brinton M. Flaviviruses. Clinical and molecular aspects of Neurotropic Virus Infection. Heidelberag: Springer; 1989:69-99.

54. Tappe D, Rissland J, Gabriel M, Emmerich, P, Gunther S, Held G, et al. First case of laboratoryconfirmed Zika virus infection imported into Europe. Euro Surveil. 2014;19(4)pii20685.

55. Factssheet for health professionals. http://ecdc.europa.eu/en/health topics/Zika virusinfection/factsheet- healthprofessionals/pages/factsheet- healthprofessionals.aspx. Accessed on 8th march, 2016.

56. Fauci AS, Morens DM. Zika virus in the Americasyet another arbovirus threat. New England journal of medicine. 2016;374(2). Available at:http://www.ncb.n/m.gov/pubmed/26761185.

57. Constancia FJ. Ayresemail identification of Zika virus vectors and implications for control Lancet Infectious Diseases. 2016.

58. Factbox-Zika virus spreads rapidly through Latin America, Carribean" news, trust.org. Thompson Reuters Foundation: Accessed 22 ${ }^{\text {nd }}$ February 2016.

59. Mitchell C.PAHO statement on Zika virus transmission and prevention," www.paho.org.pan American health organization. Accessed 22 February 2016.

60. Schuler-faccini L, Ribeiro EM, Feitosa IM, Horovitz DD, Cavalcanti DP, Pessoa A. possible association between Zika virus infection and microcephalybrazil. MMWR. 2015;65(3):59-62.

61. Zika situation report (PDF). World health organization. Accessed 22 February 2016.

62. Oduyebo $\mathrm{T}$, Petersen EE, Rasmussen SA, et al. Update; interim guidelines for health care providers caring for pregnant women and women reproductive age with possible Zika exposure - United States, 2016. MMWR. 2016;65(5):122-7.

63. Alexandra MO, John TB, Jo Ellen S. Interim guidelines for prevention of sexual transmission of Zika virus- united states, 2016. MMWR. 2016;65(Early Release):1-2.
64. Musso D, Nhan T, Robin E, Roche C, Beirlaire D, Zisou K, et al. Potential for Zika virus transmission through blood transfusion demonstrated during an outbreak in French Polynesia November 2013 to February 2014. Euro surveillance. 2014;19(14).

65. Weaver S. Evolutionary influences in arboviral disease. Quasispecies: concept and implications virology Heidelberg: Springer. 2006;285-314.

66. Cancian N. Study confirms that Zika can cross placenta during pregnancy;2016. Available at:http://www1.folha.vol.com.br/international/en/scie nceandhealth/2016/01/173143 6-study-confirms-thatZika-can-cross-plancenta-during-pregnancy.shtml. Accessed February 22, 2016.

67. Butler D. Zika virus and birth defects: what we know and we don't. 21 $1^{\mathrm{st}}$ March 2016. http://www.nature.com/news/ Zika-and-birthdefects-what-we-know-and-what-we-don't1.19596\#auth-1.

68. Zika virus: symptoms and treatment. Centers for disease control and prevention (CDC). December 28, 2015. Available http://www.cdc.gov/Zika/symptoms/index.htmI Accessed February 26, 2016.

69. Zika virus for health care providers: clinical evaluation and disease centers for disease control and prevention $\quad$ CDC). 2015 . Available at:http:/www.cdc.gov/Zika/hcproviders/clinicalevalu ation:htmI. Accessed on February 26, 2016.

70. CDC.CDC health advisory: recognizing, managing, and reporting Zika virus infections in travelers returning from central America, south America the Caribbean and Mexico; 2016. Available at:http://emergency.cdc.gov/han/han00385.asp. Accessed on February 26, 2016.

71. Interim guidelines for pregnant women during Zika virus outbreak- United States 2016. Centers for Disease Control and Prevention MMWR. 2016;65. Available at:http:/www.cdc.gov/mmwr/volumes/65/wr/pdfs/m m6502e/er.pdf. Accessed April 5, 2016.

72. Phillips D, Sun LH. Brazil may have fewer Zika related microcephaly cases than previously reported 2016.

73. Frieden T. (CDC director). Zika virus definitely causes birth defects, CDC says, CNN wire posted. April 14, 2016.

74. Cauchemez S, Besnard M, Bompard P. Association between Zika virus and microcephaly in French Polynesia, 2013-15: a retrospective study. Lancet. $15^{\text {th }}$ march 2016. (Epub ahead of print). Available at: http://dx.doi.org/10.1016/S0140-6736(16)00651-6 (2016).

75. Zika situation Report. Zika virus, microcephaly and Guillain Barre syndrome: factsheet Q \& A, key facts, more on Zika, microcephaly and Guillain Barre syndrome. 7th April 2016.

76. Boseley S. (Health editor). Zika virus: scientists present strong evidence of Guillain Barre link. 
Monday 29, February 2016 23.30GMT. Accessed on Tuesday 1st march 2016.

77. Belluz J. Simple Zika advice for women from a top CDC official. Accessed on April 29, 2016.

78. Belluz J. Zika definitely causes profound brain defects in babies. CDC. Accessed April 13, 2016.

79. Rebates.Com in Medical News: CDC confirms Zika virus causes microcephaly and other birth conditions. April 22, 2016.

80. Media statement: for immediate release. CDC concludes Zika causes microcephaly and other birth defects. Accessed on April 13 ${ }^{\text {th }}, 2016$.
81. Steenhuyen J, Berkrot B. Confirmation that Zika causes microcephaly shifts debate to prevention. Accessed on April 13, 2016.

82. Knowledge gaps. Proving Zika link to birth defects pose huge challenge. Nature. 2016;530:142-3.

Cite this article as: Okeke TC, Ezenyeaku CC, Ikeako LC, Okeke KO, Onyekwulu FA, Okafor CI, Adiri CO. Zika virus and birth defects: an obstetric issue. Int J Reprod Contracept Obstet Gynecol 2016;5:2488-96. 